\title{
SUPLEMENTASI MIKRONUTRIEN MENUNJANG EFEKTIVITAS TERAPI GIZI PADA PASIEN AKALASIA ESOFAGUS DENGAN HIPOALBUMINEMIA BERAT
}

\author{
St.Pasriany ${ }^{1}$, Agussalim Bukhari ${ }^{2}$, Haerani Rasyid ${ }^{3}$, A.Yasmin Syauki $^{4}$ \\ ${ }^{1}$ PPDS Gizi Klinik Departemen Gizi Klinik Fakultas Kedokteran Universitas Hasanuddin \\ Email :pasriarman@yahoo.com \\ ${ }^{2}$ Departemen Gizi Klinik Fakultas Kedokteran Universitas Hasanuddin, Makassar \\ Email : agussalimbukhari@yahoo.com \\ ${ }^{3}$ Departemen Gizi Klinik Fakultas Kedokteran Universitas Hasanuddin, Makassar \\ Email : haeraniabdurasyid@yahoo.com \\ ${ }^{4}$ Departemen Gizi Klinik Fakultas Kedokteran Universitas Hasanuddin, Makassar
}

\begin{abstract}
Abstrak
Pendahuluan

Akalasia merupakan gangguan motilitas berupa hilangnya peristaltik esofagus dan gagalnya sfingter esofagokardia berelaksasi, makanan tertahan di esophagus. Menyebabkan malnutrisi karena asupan tidak optimal.

\section{Laporan Kasus}

Laki-laki 64 tahun dirawat dikonsul dengan dyspepsia e.c akalasia esofagus. Keluhan utama, asupan makan berkurang dialami sejak 2 bulan karena sulit menelan dan muntah tiap kali makan. Tidak ada nyeri menelan. Demam, batuk dan sesak tidak ada. Ada penurunan berat badan, besarnya tidak diketahui. Luka pada antebrachium dekstra et sinistra. Pasien tidak menderita diabetes maupun hipertensi. Sakit sedang, GCS E4M6V5, tanda vital normal. Status gizi severe protein energy malnutrition berdasarkan ukuran LILA (18 cm). Hasil laboratorium didapatkan deplesi berat sistem imun, hipoalbuminemia dan penurunan fungsi ginjal.

Terapi nutrisi berupa diet $1430 \mathrm{kkal}$, protein $1.2 \mathrm{~g} / \mathrm{kgBBI} /$ hari dalam bentuk makanan cair via oral dan nutrisi parenteral. Kebutuhan cairan 1400ml/24 jam. Suplementasi vitamin B kompleks, zinc 20mg, pujimin 450mg, vitamin A 20.000IU, Vitamin C 300mg dan Curcuma $400 \mathrm{mg} / 8 \mathrm{jam}$. Pemantauan asupan, toleransi saluran cerna, tanda vital dan keseimbangan cairan setiap hari.

Setelah perawatan 41 hari, pasien dapat menelan makanan lunak, luka pada antebrachium menutup, tidak terjadi perburukan status gizi, albumin dan protein total meningkat.
\end{abstract}

\section{Kesimpulan}

Hipoalbuminemia pada pasien akalasia esofagus, efusi pleura bilateral, skin and soft tissue infection terkoreksi dengan asupan protein 1,2 gr/kgBBI/hari, Zinc $20 \mathrm{mg}$, vitamin B kompleks, Pujimin $450 \mathrm{mg}$, Vitamin A $20.000 \mathrm{IU}$, Vitamin C $300 \mathrm{mg}$ dan Curcuma $400 \mathrm{mg} / 8$ jam/oral.

Kata kunci : Mikronutrien, Akalasia esofagus, hipoalbuminemia.

\section{Latar belakang}

Akalasia didefenisikan sebagai gangguan motilitas berupa hilangnya peristaltik esofagus dan gagalnya sfingter esofagokardia berelaksasi sehingga makanan tertahan di esophagus. Dapat menyebabkan malnutrisi karena asupan yang tidak optimal. Insiden 6/100.000 orang/tahun. Banyak 
diderita oleh wanita muda, pria dan wanita paruh baya. ${ }^{1,2}$ Adanya kelainan persarafan parasimpatis berupa hilangnya sel ganglion plexus auerbach (pleksus mesenterikus) yang diduga terjadi akibat proses autoimun atau infeksi kronis. Akalasia diduga terjadi degenerasi neurogenik, dapat idiopatik ataupun karena infeksi. Beberapa faktor lain seperti stres emosional, trauma, penurunan berat badan yang drastis, dan penyakit Chagas (infeksi parasit dengan Trypanosoma cruzi) telah terjadi. ${ }^{1,2}$

Trias klasik dari gejala-gejala yang muncul adalah disfagia, regurgitasi dan penurunan berat badan. Meskipun demikian, heartburn, tersedak setelah makan (postprandial choking), dan batuk nokturnal sering terlihat. Disfagia yang dialami pasien mulai dari makanan cair hingga makanan padat. Saat tekanan intratorakal meningkat, nyeri dada retrosternal mulai timbul. Regurgitasi makanan yang tidak tercerna, dan berbau busuk. Dapat terjadi aspirasi yang mengancam jiwa. Pneumonia, abses paru dan bronkiektasis sering merupakan hasil dari long standing achalasia. Pasien dengan gizi baik akan berubah menjadi gizi kurang bahkan dapat berlanjut menjadi gizi buruk. ${ }^{1,2}$
Terapi akalasia dapat berupa terapi bedah dan non bedah, namun keduanya diarahkan pada penurunan obstruksi lower esophagus spinchter (LES). ${ }^{3}$

\section{Laporan Kasus}

Laki-laki 64 tahun dirawat di RSUH dikonsul ke bagian Gizi Klinik dengan dyspepsia ec akalasia esofagus. Keluhan utama pasien adalah asupan makan berkurang yang dialami sejak 2 bulan lalu karena sulit menelan dan muntah tiap kali makan. Tidak ada nyeri menelan. Tidak demam, tidak batuk dan tidak sesak. Ada penurunan berat badan namun besarnya tidak diketahui.

Tidak ada riwayat hipertensi dan Diabetes Melitus. Sering mengalami nyeri lambung dan kembung. Tidak ada riwayat hipertensi dan diabetes melitus dalam keluarga. Tidak ada riwayat merokok dan tidak ada riwayat minum alkohol. Pasien bekerja sebagai petani.

Dalam 10 tahun terakhir pasien hanya makan bubur karena rasa tidak enak pada perut jika makan nasi. Dalam 2 bulan terakhir makan bubur hanya $1 / 2$ porsi dari biasanya. Dan memburuk dalam 2 minggu terakhir, hanya makan 3-5 sendok bubur tiap kali makan. Dalam 3 hari terakhir tidak 
makan sama sekali. Food recall 24 jam Energi 0 kkal, selama 3 hari.

Pasien nampak sakit sedang, GCS E4M6V5, tanda vital normal. Ukuran lingkar lengan atas $(18 \mathrm{~cm})$. Akses sentral telah terpasang. Edema pada dorsum pedis. Lost of subcutaneous fat ada. Luka pada antebrachium dekstra et sinistra. Pasien tidak menderita diabetes maupun hipertensi.

\section{Diagnosis dan penilaian penting}

Status gizi pasien adalah severe protein energy malnutritian berdasarkan ukuran lingkar lengan atas $(18 \mathrm{~cm})$. Pada pemeriksaan laboratorium didapatkan adanya deplesi berat sistem imun, hipoalbuminemia dan penurunan fungsi ginjal.

\section{Tatalaksana}

Terapi gizi yang diberikan berupa nutrisi $1430 \mathrm{kkal} / \mathrm{hari}$ dengan protein 1.2 g/kgBBI/hari. Hari pertama direncanakan 40 $\% \operatorname{KET}(560 \mathrm{kkal})$ via oral berupa formula entramix 6 x 65 kkal via oral. Parenteral dengan aminofluid $500 \mathrm{ml} / 24$ jam. Kebutuhan cairan 1400 ml/hari via oral, oral dan parenteral. Suplementasi yang diberikan Neurodex 1 tablet/ 24 jam, Zinc 20 mg/24 jam, Pujimin 2 kapsul/8 jam, vitamin 20.000
IU/24 jam, curcuma $400 \mathrm{mg} / 8 \mathrm{jam}$, dan vitamin C 300 mg/24 jam. Jumlah kalori ditingkatkan sesuai dengan toleransi pasien.

Makanan cair diberikan sesuai toleransi pasien dengan porsi kecil dan diberikan sering sampai hari ke 30 perawatan. Businasi dilakukan oleh teman sejawat bedah. Hari ke 31 perawatan pasien mulai diberi bubur saring, formula tinggi protein, jus buah dan jus buah. Hari ke 33 beralih menjadi bubur biasa hingga pasien pulang, diselingi dengan formula tinggi protein (peptisol dan peptamen). Nutrisi parenteral diberikan sampai kebutuhan tercukupi melalui oral.

\section{Follow up dan outcome}

Pemantauan dan evaluasi terhadap tanda vital (hemodinamik), keseimbangan cairan/hari, asupan/hari, antropometri / minggu, darah rutin, fungsi hati, fungsi ginjal, albumin. Kerjasama dan komunikasi yang baik dengan keluarga, dokter penanggung jawab utama pasien (dokter bedah digestif). Memberikan edukasi gizi pada keluarga pasien tentang pemberian makanan secara bertahap untuk mencapai kebutuhan energi disesuaikan kondisi pasien, pengaruh nutrisi terhadap proses penyembuhan penyakit. 
Asupan total energi selama masa rawat tergambar dalam grafik 1 dan asupan protein dapat dilihat pada grafik 2, asupan karbohidrat pada grafik 3 dan asupan lemak pada grafik 4 .

Asupan energi mencapai target 100 $\%$ pada hari ke 35. Sebelumnya asupan sangat sulit mencapa target karena pasien sering dipuasakan untuk tindakan invasive tertentu dari ts bedah.

Asupan protein sangat berfluktuasi dari hari ke hari karena toleransi pasien yang berubah-ubah dan baru mencapai target pada akhir masa rawat.

Asupan karbohidrat juga mencapai target pada hari rawat ke 35 dan meningkat terus hingga akhir masa rawat.

Asupan lemak juga sangat berfluktuasi, target $100 \%$ tercapai pada hari ke 38 hingga akhir masa rawat. Hal ini juga sangat tergantung pada toleransi pasien.

Monitoring antropometri dalam hal ini LILA dilakukan setiap minggu. Hasil pengukuran LILA setiap minggu dapat dilihat pada grafik 5 .

Awal masa rawat hingga hari ke 21 terjadi penurunan LILA dari $17,2 \mathrm{~cm}$ menjadi 16,4 cm. Setelah hari 21 ukuran LILA baru mulai bertambah.
Perubahan kadar albumin serum juga dikontrol setiap minggu. Hasil pengukuran albumin serum dapat dilihat pada grafik 6 .

Albumin pada awal masa rawat hingga hari ke 28 menurun dan mulai mengalami peningkatan setelah hari rawat ke 28 .

\section{Diskusi}

Status gizi pasien ini ditentukan berdasarkan Lingkar Lengan Atas $(18 \mathrm{~cm})$. Penyakit dyspepsia yang dialami pasien dalam waktu lama menyebabkan asupan makan sangat tidak mencukupi kebutuhan tubuh pasien. Hal ini akan menyebabkan proteolisis dan lipolisis sehingga terjadi kehilangan lemak subkutan dan wasting otot. $^{4}$

Protein bukan hanya berfungsi sebagai unsur utama penyusun struktur tubuh tapi juga terdapat protein fungsional yang memiliki fungsi khusus. Protein tersebut adalah protein fungsional, seperti hemoglobin, dan komponen darah yang lain. Sistem imun pun terbentuk dari protein khsusus. Deplesi system imun terjadi karena protein fungsional untuk system imunitas pun jumlah jauh berkurang karena proteolisis tersebut. ${ }^{5}$

Albumin, protein plasma yang berperan dalam mempertahankan tekanan 
osmotik koloid plasma. Hipoalbuminemia disebabkan oleh beberapa faktor antara lain berkurangnya sintesa albumin, meningkatnya kehilangan albumin dari tubuh, redistribusi albumin dari intravaskuler ke ekstravaskuler dan dilusi albumin intravaskuler. ${ }^{6}$ Hipoalbuminemia menyebabkan penurunan tekanan osmotic plasma, cairan plasma akan bergerak ke interstitial, terjadilah edema. Hipoalbuminemia pada pasien ini terjadi karena beberapa faktor yaitu asupan yang kurang, inflamasi, dan infeksi luka. 6,7,8 Terapi nutrisi yang diberikan untuk mengatasi hipoalbuminemia adalah asupan protein mulai 1 gram $/ \mathrm{kgBB} /$ hari ditingkatkan secara bertahap hingga mencapai 1,2 gram/kgBB/hari dalam bentuk formula tinggi protein dan solusi protein (parenteral). Ditunjang oleh suplementasi mikronutrien yang penting dalam menekan inflamasi zink 20mg, vitamin A 20.000 IU, dan vitamin C 300mg. Kadar albumin pasien yang sebelum intervensi $2.1 \mathrm{~g} / \mathrm{dL}$ kemudian meningkat menjadi $2.7 \mathrm{~g} / \mathrm{dL}$ dan pada akhir perawatan kadar albumin menjadi $3.0 \mathrm{~g} / \mathrm{dl}$.

Skin and Soft Tissue Infection yang dialami oleh pasien karena pemberian cairan intravena yang memiliki osmolalitas yang tinggi yang diberikan secara perifer sebelumnya. Membran sel menjadi lisis akibat osmolalitas cairan yang tinggi. Akhirnya kulit dan jaringan lunak sekitarnya menjadi nekrosis. Keadaan ini diperparah oleh sistem imun pasien yang sangat buruk sehingga penyembuhan menjadi semakin sulit. Diet protein tinggi pada pasien penting dalam proses penyembuhan luka. 7,8,9 Defisiensi protein dapat mengganggu proses penyembuhan luka pada semua fase penyembuhan luka. Deplesi protein menghambat penyembuhan luka dengan memperpanjang fase inflamasi, menghambat sintesa kolagen dan proteoglikan, menghambat angiogenesis dan menghambat proses remodelling luka. ${ }^{10,11}$

Lemak, bersama dengan karbohidrat digunakan sebagai sumber energi yang dapat mencegah penggunaan protein sebagai sumber energi. Lemak juga dibutuhkan untuk absorbsi vitamin A yang diperlukan dalam penyembuhan luka. Lemak dibutuhkan untuk pertumbuhan jaringan dan remodeling luka termasuk produksi kolagen dan matriks ekstraseluler. Asam lemak esensial harus dikonsumsi. Asupan tinggi MUFA dan omega 3 PUFA adalah penting untuk penyembuhan luka, selain sebagai sumber lemak juga berfungsi sebagai antiinflamasi yang dibutuhkan setelah fase 
inflamasi pada proses penyembuhan luka. Sedangkan SAFA digunakan sebagai sumber energi siap pakai. ${ }^{5,11,12}$ Pada pasien ini lemak yang diberikan berasal dari lauk pauk nabati dan hewani (daging ayam/sapi,tahu, tempe dan telur) dan minyak zaitun (olive oil).

Mikronutrien yang berperan terhadap penyembuhan luka yang diberikan pada pasien adalah zink (20 mg), vitamin A (18.000 IU), vitamin B (vitamin B1 100 $\mathrm{mg}$, vitamin B6 $100 \mathrm{mg}$, dan vitamin B12 $5000 \mathrm{mcg}$ ), dan vitamin C (300 mg). Zink dibutuhkan untuk sintesis DNA, pembelahan sel, dan sintesis protein. Vitamin A dibutuhkan untuk fase inflamasi awal pada penyembuhan luka, mendukung diferensiasi sel epitel, memperbaiki lokalisasi serta stimulasi respons imun. Vitamin B dibutuhkan sebagai kofaktor dari berbagai enzim yang berperan dalam metabolisme makronutrien. Vitamin $\mathrm{C}$ dibutuhkan untuk sintesis kolagen, proteoglikan, dan komponen organik lainnya dari matriks intraseluler; antioksidan jaringan, dan mendukung respons imun. Vitamin $\mathrm{C}$ juga membantu mempercepat proliferasi sel-sel imun. ${ }^{9,10,11,13}$. Intervensi gizi yang diberikan terhadap penanganan luka pada pasien ini menunjukkan adanya perbaikan pada luka regio antebrachium pasien.

Pada kasus ini penting dilakukan edukasi baik pada pasien dan keluarganya. Tujuan edukasi gizi pada pasien dan keluarganya adalah untuk meningkatkan pengetahuan gizi pasien dan keluarganya, sehingga pasien dan keluarganya mengerti mengenai program, maksud dan tujuan intervensi gizi yang diberikan pada pasien.

\section{Kesimpulan}

Terapi gizi yang optimal dengan protein 1,2 $\mathrm{g} / \mathrm{kgBBI} / \mathrm{hari}$ dalam bentuk makanan cair porsi kecil frekuensi sering dengan suplementasi nutisi parenteral didukung suplementasi mikronutrien yaitu zink 20mg, vitamin A 20.000IU, vitamin B kompleks dan vitamin C 300mg, pujimin $450 \mathrm{mg}$, curcuma $400 \mathrm{mg} / 8$ jam dapat meningkatkan kadar albumin dan protein serum, dan mempercepat penyembuhan luka pada pasien dengan akalasia esophagus.

\section{Informed consent}

Pasien dan keluarga telah mendapat penjelasan dan menyetujui prosedur dan tujuan semua tindakan yang akan dilakukan termasuk terapi gizi. 


\section{Daftar Pustaka}

1. O'neil OM, Johnston BT, Coleman HG. 2013 Achalasia : a review of Clinical diagnosis, epidemiology, treatment and outcomes. Wordl J Gastroenterol.

2. Patel et al. 2015. Idiopathic (primary) achalasia : a review. Orphanet Journal of Rare Disease. DOI 10.1186/s13023-0150302-1.

3. Zaninott G, et al. 2000. Treatment of esophageal achalasia with laparoscopic Heller myotomi. J Gastrointest Surg.

4. Gautron L., Layé S 2010. Neurobiology of inflammation-associated anorexia. Online available at: $\underline{w w w . f r o n t i e r s i n . o r g}$

5. Demling, RH., 2009. Nutrition, Anabolism, and the Wound Healing Process: An Overview. Journal of Plastic Surgery

6. Throop JL., et.al., 2004. Albumin in health and disease: Causes and Treatment of Hypoalbuminemia. Online, available at : www.VetLearn.com

7. Casqueiro J., et.al., 2012. Infections in patients with diabetes mellitus: A review of pathogenesis. Indian Journal of Endocrinology and Metabolism. Online available

at

http://www.ncbi.nlm.nih.gov/pmc/articles/P MC3354930/

8. Katona P., et.al., 2008. The Interaction between Nutrition and Infection. Infectious Diseases Society of America.

9. MacKay, D., Miller, A L., 2003. Nutritional Support for Wound Healing. Alternative Medicine Review . Volume 8, Number 4

10.Chattopadhyay I., et.al., 2004. Turmeric and curcumin: Biological actions and medicinal applications. Current science.

11.Nestle Health Science, 2013. Nutrients Involved in the Wound Healing Process. Online, available at www.NestleHealthScience.us

12. Fernandez, M.L., et.al., 2005. Mechanisms by which Dietary Fatty Acids Modulate Plasma Lipids. American Society for Nutritional Sciences.

13. Wu NC, 2003. Safety and AntiInflammatory Activity of Curcumin: A Component of Tumeric (Curcuma longa). The journal of alternative and complementary medicine Volume 9, Number 1 


\section{Grafik 1. Asupan Energi}

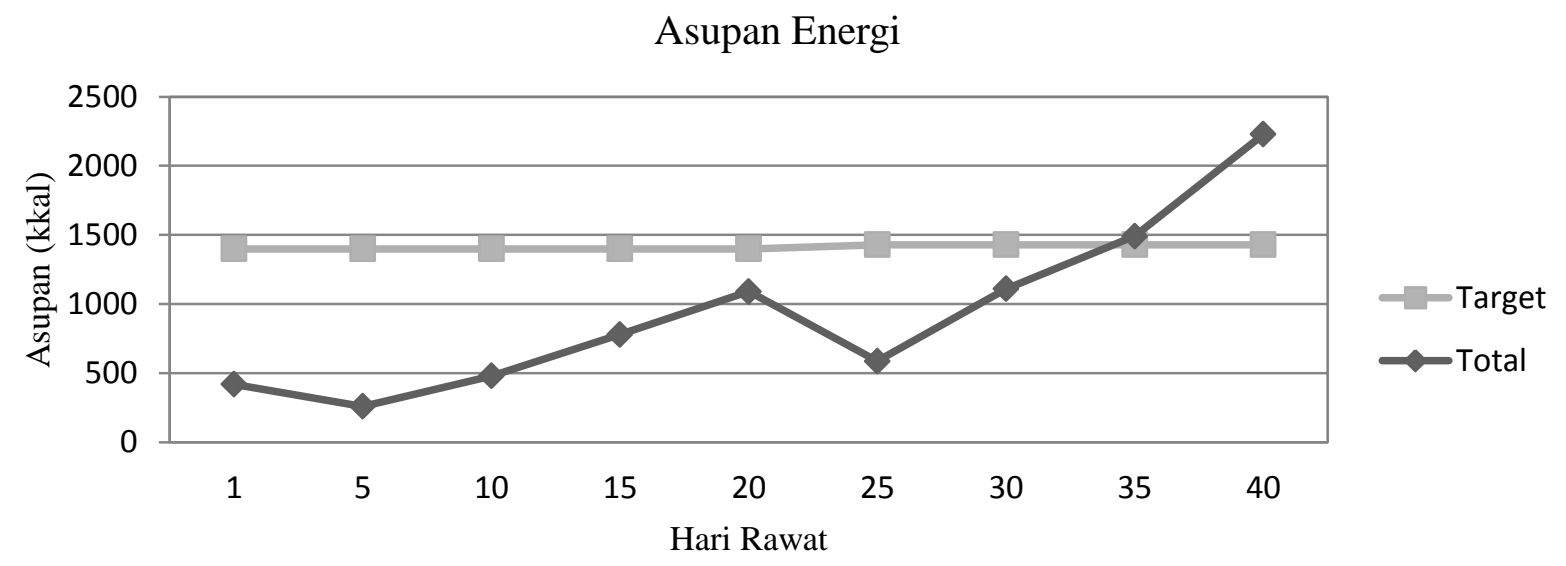

\section{Grafik 2. Asupan Protein Harian}

Asupan Protein

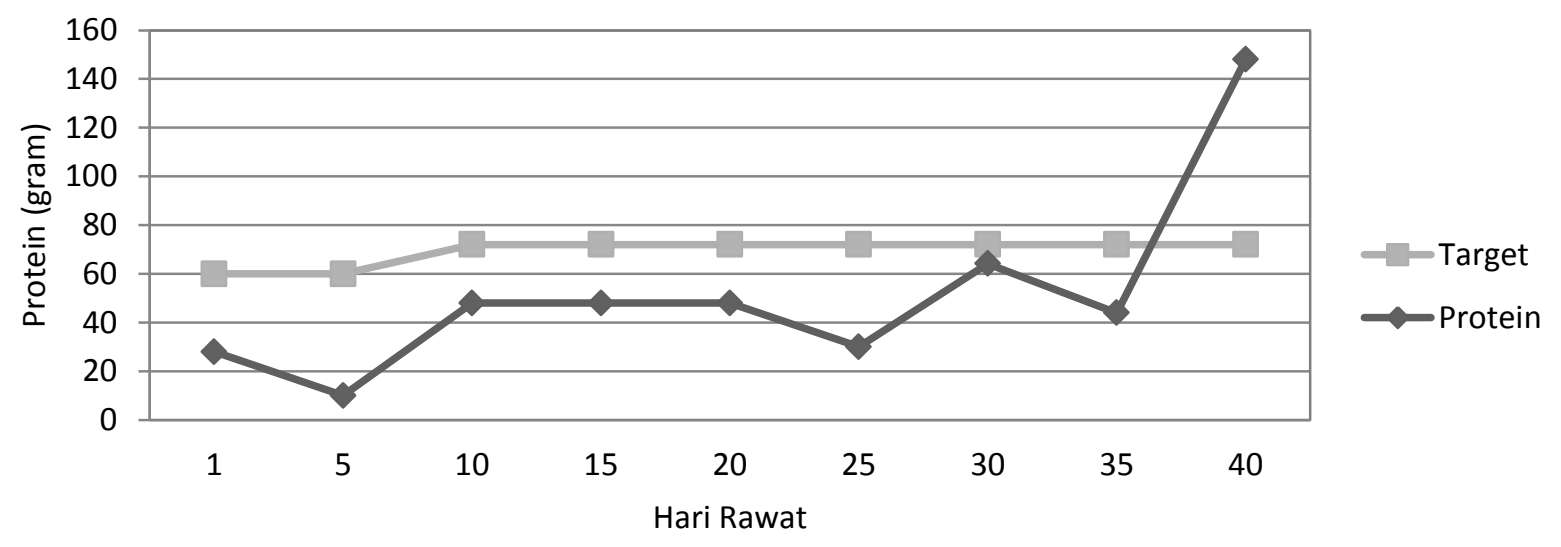

\section{Grafik 3. Asupan Karbohidrat Harian}

Asupan Karbohidrat

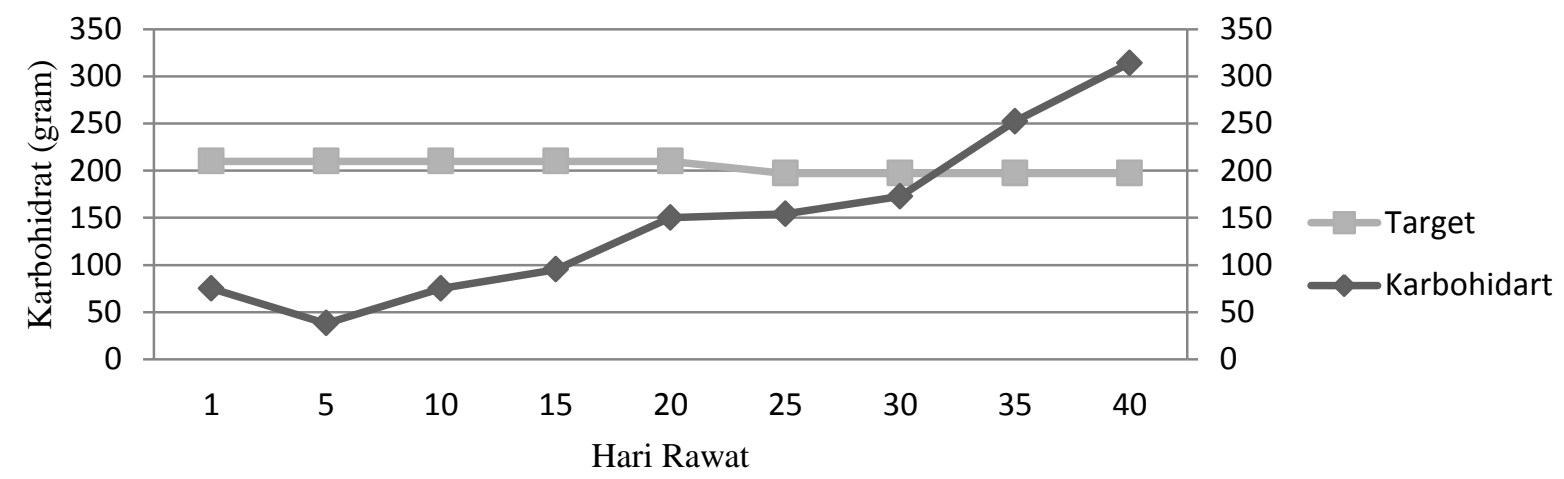




\section{Grafik4. Asupan Lemak Harian}

Asupan Lemak

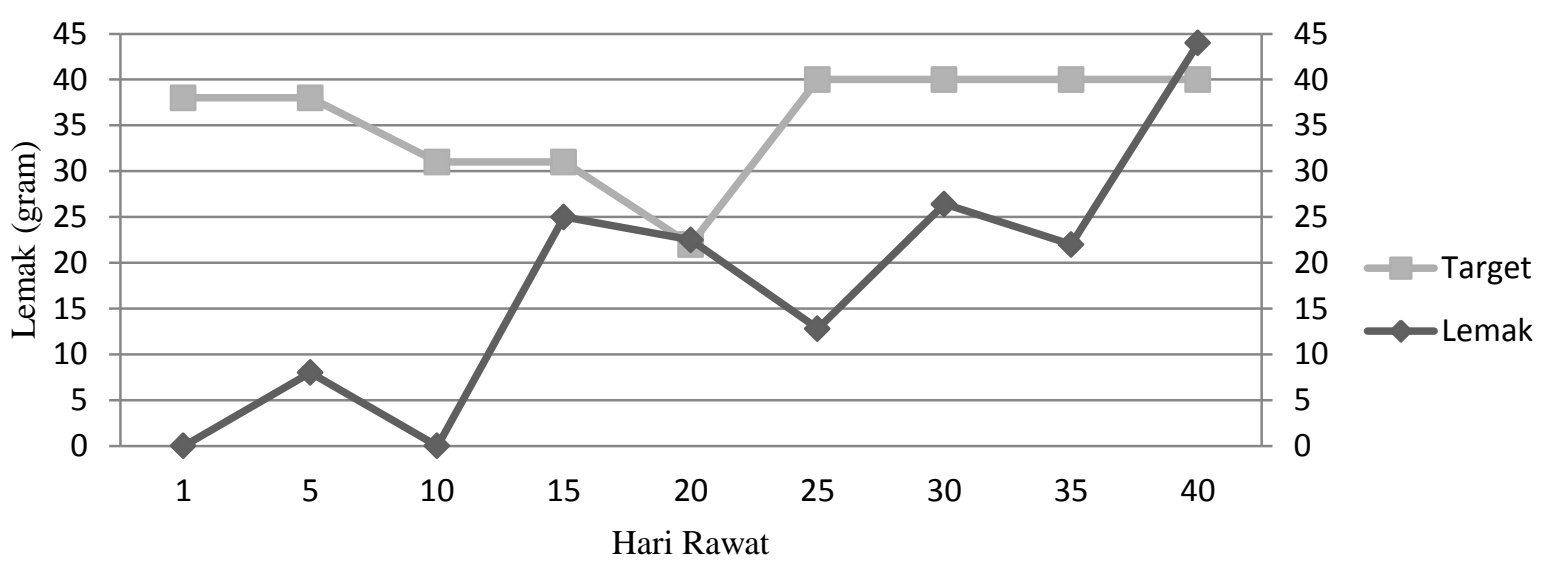

\section{Grafik 5. Monitoring Lingkar Lengan Atas}

Lingkar Lengan Atas

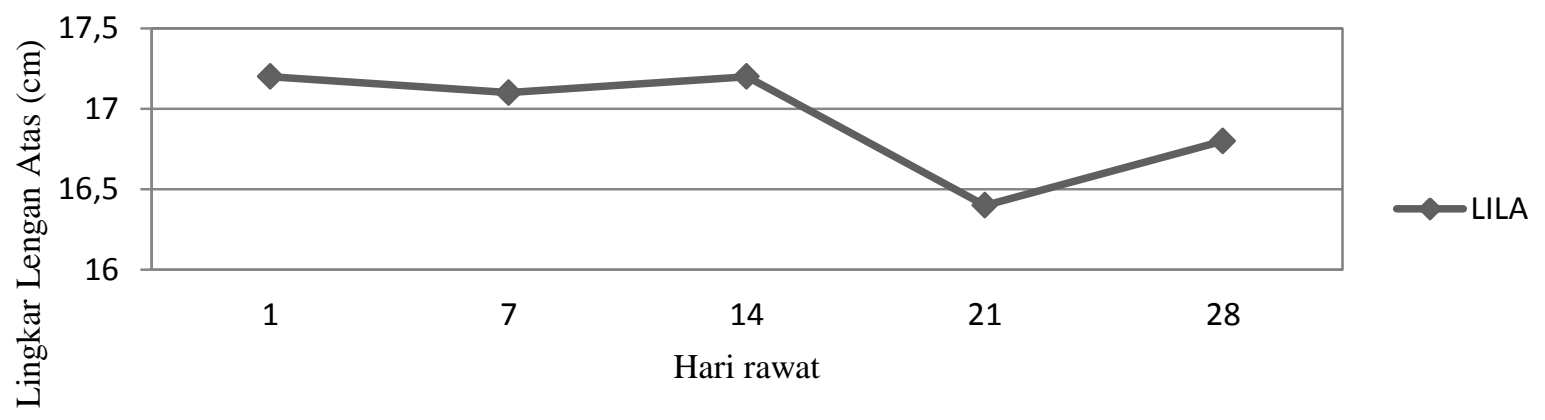

\section{Grafik 6. Albumin serum}

Monitoring Albumin

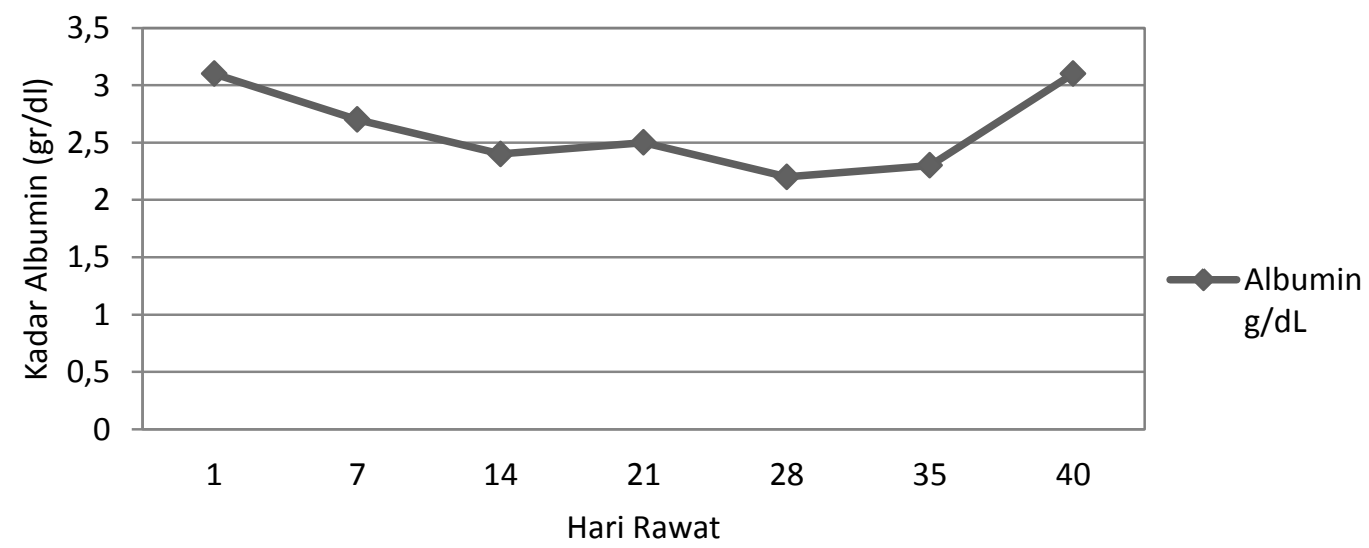

